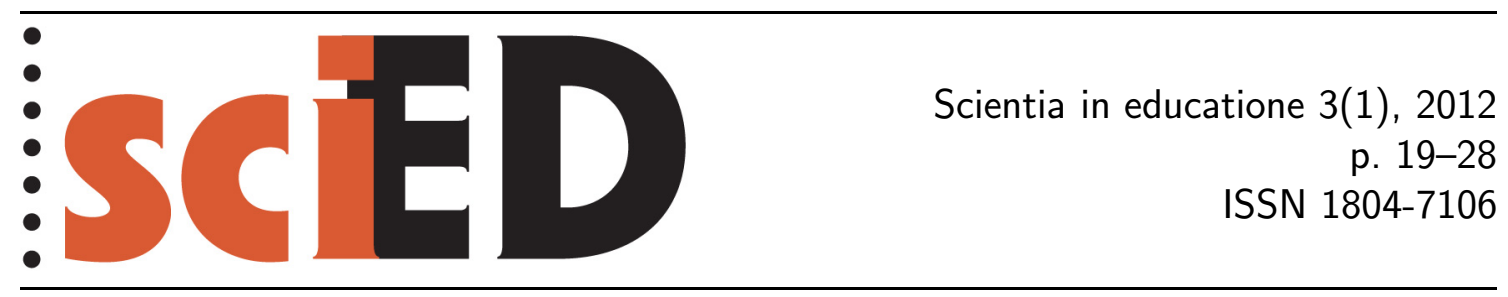

\title{
Evaluační standardy vzdělávacího oboru Chemie - reflexe nově vzniklých Standardů základního vzdělávání
}

\author{
Svatava Janoušková, Jan Maršák, Václav Pumpr
}

\begin{abstract}
Abstrakt
Evaluační standardy, které byly v posledních dvou letech vytvářeny pracovními skupinami pod vedením Ministerstva školství, mládeže a tělovýchovy, jsou aktuálním tématem diskuzí odborné i laické veřejnosti. V našem článku přinášíme informaci o vymezení pojmu „standard“ a jeho roli v českém vzdělávacím systému v posledních 20 letech. Dále předkládáme reflexi evaluačního standardu vzdělávacího oboru Chemie, jež je součástí Standardů základního vzdělávání z pozice tvưrců těchto standardů, a přinášíme návrh indikátorového listu pro optimální zpracování indikátorů v evaluačních standardech.
\end{abstract}

Klíčová slova: standard, standard vzdělávání, indikátor, evaluační standard vzdělávacího oboru Chemie.

\section{Evaluation Standards of Chemistry - Reflection of New Standards of Primary Education}

\begin{abstract}
The Ministry of Education, Youth and Sports in cooperation with expert groups finished the evaluation standards for most educational areas last year. These standards have become a hot topic and are the matter of current discussions of didactic experts as well as the lay public. Our paper deals with a definition of the term "standard" and explains the role of standards in the Czech educational system in the last 20 years. It also reflects the newly developed Chemistry evaluation standard and proposes a format of indicator fact sheets for effective standards processing.
\end{abstract}

Key words: standard, educational standard, indicator, chemistry evaluation standard. 


\section{1 ÚVOD}

Se slovem standard a slovy, která jsou od něho odvozena (taková jako standardní, standardizace apod.) se setkáváme velmi často, téměř na každém kroku. Mluví se např. o standardech jednání mezi jednotlivci, mezi skupinami jednotlivců či mezi státy, o právních standardech, o standardech zdravotní péče (dnes tak často diskutovaných - viz např. Standardy zdravotní péče, 2009), o standardech vzdělávání či vzdělání (a v této souvislosti o cílových standardech či standardech evaluačních - viz např. MŠMT, 2011) a někdy dokonce i o standardním občanovi. Termín standard a termíny od něho odvozené se tak rozšířily v běžné i odborné řeči, že jsme jimi často doslova zaplaveni.

Tento článek se pokouší přiblížit termín standard, tj. osvětlit podrobněji významy pojmů, jež uvedený termín označuje. Dále se zabývá rolí standardu v českém vzdělávacím systému v historickém kontextu, a nakonec přináší pohled na nově vytvářené evaluační standardy. Tyto evaluační standardy jsou reflektovány na př́kladech standardů chemie, které na konci roku 2011 prošly veřejným připomínkovým řízením.

\section{POJEM STANDARDU: JEHO MOŽNÉ VÝZNAMY}

Termín standard má svůj původ v anglickém slově standard (nebo lépe řečeno ve starofrancouzském estandard), kde mělo dva základní významy: označovalo jednak praporec (vlajku, korouhev) a jednak něco ustanoveného jako základ, či referenční míra pro srovnání, posuzování nebo hodnocení. Význam anglického slova standard se postupně rozšiřoval a v soudobé angličtině tak můžeme najít už více jak dvacet jeho významů (Velký anglicko-český slovník, 1984). Ty ovšem v zásadě vždy v nějakém rozsahu reflektují výše uvedené dva původní významy.

V českém jazyce můžeme ovšem termín standard pro označení praporce rovnou vyloučit, nebot v tomto případě máme vhodnější termín, a to standarta (z německého die Standarte). Pak nám zbývá jen druhý hlavní význam, tj. základ či referenční míra pro srovnání, posuzování nebo hodnocení. Přitom samotné ustanovení (určení, vymezení, definování) této míry může být nap̌r. výsledkem dohody (konvence), praktické vhodnosti či potřebnosti nebo i tradice. V pozadí ale vždy stojí snaha mít k dispozici jisté kritérium pro porovnání aspektů téhož druhu: co je totiž „níže“ než standard je (z určitého pohledu) vždy méně hodnotné, užitečné apod. než to, co je standardní nebo to, co je „výše“ než standard. Standardy, především pak ty pro oblast psychosociální reality, jsou často určovány pod vlivem hodnotového systému či morálního kódu přijatého danou komunitou (společenstvím). Standardy tak nejsou hodnotově neutrální a jejich zavádění či transformace mohou proto být zdrojem mnoha, často ostrých, ideologických kontroverzí.

V souvislosti s vymezení pojmu standard se ještě zmiňme o dalších dvou pojmech: norma a etalon (prototyp).

Standard a norma se někdy považují za významově totožné, jindy se rozlišují. Rozlišení se pak uvažuje ze dvou hledisek. Z jednoho hlediska je norma považována za standard, který je ovšem nutno povinně dodržet či plnit. V tomto pojetí je tedy každá norma standardem, ale ne každý standard musí být normou. Z druhého hlediska je norma chápána nikoli jako míra, ale spíše jako pravidlo, které je nutno použít či dodržet, aby danou úroveň bylo možno dosáhnout. V tomto smyslu pak existují přinejmenším čtyři různé druhy norem: technické normy, sociální normy, právní normy a morální pravidla (Bunge, 2003). 
Pokud jde o relaci mezi pojmy standard a etalon lze říci, že jsou si významově velmi blízké. I etalon se chápe především jako předem stanovená míra pro porovnání, ale navíc explicitně považovaná za úroveň v daném případě „kvalitativně“ nejvyšší. Termín etalon je dnes používán v první řadě v oblasti metrologie a tam výlučně vždy pro označení objektu či procesu, jež reprezentuje v nejvyšší dostupné míře přesnosti danou jednotku měření (např. etalon jednotky hmotnosti je těleso určitých vlastností uložené v Mezinárodním úřadu pro míry a váhy v Sévres u Pařǐže ve Francii). Etalony jednotek jsou nezbytným základem pro realizaci přesných a srovnatelných fyzikálních měření, což je nezbytný předpoklad rozvoje vědeckého a technologického poznání. (O etalonech jednotek viz napřr. webové stránky Českého metrologického institutu.)

\section{STANDARD VZDĚLÁNí}

Myšlenka standardu, resp. standardů vzděláni (či vzdělávání) se u nás začala objevovat na počátku devadesátých let minulého století, a to především v souvislosti s určitými liberalizačními tendencemi zasahujícími tehdy velmi intenzivně naše školství a následnou snahou tyto tendence nějakým způsobem centrálně regulovat. Výsledkem takové snahy bylo vytvoření tzv. standardů vzdělávání.

V roce 1995 tak vznikl dokument MŠMT Standard základního vzdělávání (1999) a v roce 1996 Standard vzdělávání pro čtyřleté gymnázium (1999). (Vznikl i Standard středního odborného vzdělávání, ale tím se zde už nezabýváme.) Byt se tyto dokumenty nazývaly standardy, byly poměrně stručné a jednalo se o standardy cílové a obsahové. Nevymezovaly už ale ty podrobnosti, které byly uváděny v před tím centrálně připravovaných učebních osnovách. Posledně zmiňované standardy určovaly z úrovně státu pouze (výstupní) strategické vzdělávací cíle (poznávací cíle, dovednosti a kompetence, hodnoty a postoje) pro daný stupeň vzdělávání, rozčlenění vzdělávacího obsahu do tzv. oborů a předmětů pro daný stupeň vzdělávání, strategické cíle oborů resp. předmětů na daném stupni vzdělávání a jen velmi rámcově vymezovaly vzdělávací obsah jednotlivých předmětů, neboli tzv. kmenové učivo (což bylo učivo považované pro daný stupeň vzdělávání v daném předmětu za neopominutelné a tedy povinné pro všechny žáky). Standardy však již školám direktivně neurčovaly, jak mají učivo strukturovat do ročníků či v jednotlivých ročnících, nestanovovaly časové dotace pro jednotlivé obory či předměty a už vůbec neurčovaly, jaké výukové metody mají učitelé používat při výuce ve třídě. V tomto pojetí standardy na jedné straně dovolovaly školám autonomní chování v mnohem větší míře, než tomu bylo před tím, ale na druhé straně ještě stále umožňovaly v celostátním rámci zachovávat společné směřování škol, pokud se jednalo o strategické vzdělávací cíle a o kmenové učivo.

Na uvedené standardy vzdělávání pak navazovaly tzv. vzdělávací programy. Tyto vzdělávací programy byly pedagogické dokumenty, které specifikovaly standardy vzdělávání v oblasti cílů a vzdělávacího obsahu, popř. specifikovaly i další charakteristiky vzdělávacího procesu (učební plán, metody výuky, její organizaci apod.). Umožňovaly tak školám realizovat své vlastní představy o vzdělávání v jeho jednotlivých segmentech, ovšem při zohlednění parametrů, které byly nastaveny ve standardech.

Uvedené vzdělávací programy si mohly školy vytvářet samy, ale aby podle nich mohly pracovat, musely být schváleny MŠMT ČR. Mohly však také použivat i vzdělávací programy připravené centrálně (ze státní úrovně). Pro základní školu byly takto centrálně připraveny tři vzdělávací programy: vzdělávací program Základní škola, vzdělávací program Národni škola a vzdělávací program Obecná škola (tento 
program vznik sloučením dřivějších programů Obecná škola a Občanská škola). Všechny tyto programy musely splnit požadavky Standardu základního vzdělávání, pokud jde o cíle vzdělávání a kmenové učivo jednotlivých předmětů, ale mohly si autonomně nastavit učební plán, strukturu vzdělávacích obsahů jednotlivých předmětů, organizaci výuky apod. Uvedené vzdělávací programy pro základní vzdělávání mohly školy dokonce kombinovat, např̀. na prvním stupni ZŠ mohly používat program Obecná škola a na druhém stupni program Základni škola či Národní škola, nebo mohly použivat různé programy v paralelních tř́idách atd.

Pokud se jedná o gymnázium, tam př́mo nevznikly analogické vzdělávací programy jako na ZŠS, ale přesto došlo z centrální úrovně ke specifikaci Standardu vzdělávání pro čtyřleté gymnázium, která měla formu tzv. Učebních dokumentů pro gymnázia (1999). Tyto dokumenty obsahovaly konkretizované tzv. generalizované učební plány, dále učební osnovy jednotlivých předmětů a určité poznámky $\mathrm{k}$ přistupům a organizaci výuky jednotlivých předmětů - a to jak pro čtyřletý cyklus, tak pro osmiletý cyklus gymnázia.

$\mathrm{Na}$ přelomu tisíciletí pak dochází $\mathrm{k}$ další fázi $\mathrm{v}$ reformě primárního a sekundárního vzdělávání. Opouští se ovšem pojem standardu vzdělání, resp. standardu vzdělávání a zavádí se z centrální úrovně tzv. rámcové vzdělávací programy (RVP). Vznikají tak Rámcový vzdělávací program pro základni vzděláváni (RVP ZV), Rámcový vzdělávací program pro gymnázium (RVP G) a Rámcové vzdělávací programy pro středni odborné školy (RVP SOŠ). Ale i přes změnu terminologie jsou RVP též standardy vzdělávání, a to opět standardy cílovými a obsahovými. Oproti standardům z let devadesátých, jsou ovšem poněkud podrobnější a obsahují i další složky, které se v prvně jmenovaných dokumentech nevyskytovaly (podrobněji viz citované RVP). Vytěsňují také donedávna platné vzdělávací programy.

$R V P$ jsou celostátními standardy vzdělávání pro příslušné stupně vzdělávání a jsou základem, referenční mírou pro tvorbu tzv. školních vzdělávacích programů $(\breve{S} V P)$, v nichž si jednotlivé školy, při dodržení všech parametrů stanovených v $R V P$, formulují způsob vzdělávání svých žáků podle specifických podmínek a možností tak, aby cíle a př́islušný vzdělávací obsah naplnily co nejlépe a co nejefektivněji. Ve $\breve{S} V P$ mohou školy vzdělávací obsahy, vymezené v $R V P$ ve vzdělávacích oborech, strukturovat a kombinovat do tzv. vyučovacích předmětů, jak uznají za vhodné a jak jim to nejlépe vyhovuje z hlediska jejich potřeb a potřeb jejich žáků. Jedinou podmínkou je, že ve vzdělávacím obsahu povinných vyučovacích předmětů v $\breve{S} V P$, musí být reflektován veškerý vzdělávací obsah oborů z $R V P$. V tomto smyslu je každý $\breve{S} V P$ též standardem vzdělávání, nebot je stanovenou referenční mírou vzdělávání, jíž se řídí ta či ona škola.

$\breve{S} V P$ nepodléhá schvalovací proceduře MŠMT, schvaluje ho pouze ředitel dané školy. Na rozdíl od reformy z let 1995-1996, kdy si školy též mohly vytvářet samy vzdělávací programy, ale schválit jim je muselo MŠMT, je poslední reforma dalším krokem k posílení vzdělávací autonomie škol. Kontrolu toho, zda daná škola plní v patřičném rozsahu i kvalitě to, co si vymezila ve svém $\breve{S} V P$, má na starosti Česká školni inspekce.

V poslední době se koncept standardu vzdělání opět vrací, ovšem v poněkud jiném (opačném) pojetí, než tomu bylo v devadesátých letech minulého století. Standardy vzdělávání se zde vymezují pro jednotlivé vzdělávací obory, které jsou součástí $R V P$ $Z V$, a to ve formě specifikace, resp. konkretizace očekávaných výstupů náležejících k přrislušnému vzdělávacímu oboru (viz Standard základního vzdělávání, 2011). Tyto standardy se nazývají minimální cílové evaluační standardy. Poznamenejme jen, že takto zpracované standardy jsou skutečně cílové, ale podle našeho názoru v po- 
době předložené k připomínkovému řízení za další vzdělávací obory nikoli evaluační, ale opět pouze obsahové. Evaluační nejsou proto, že pouhá specifikace obecnějšího očekávaného výstupu není ještě evaluačním prostředkem, ale pouze nutným předpokladem pro konkrétní evaluaci. Evaluačním prostředkem, resp. evaluačním standardem bude až systém konkrétních úloh (nebo jiných metod měření žákovských znalostí), prostřednictvím nichž budeme ověřovat splnění konkrétně nastaveného cílového a obsahového standardu.

Zmiňme ještě jeden terminologický aspekt. Ve Standardech základního vzdělávání (SZV, 2011) se mluví o indikátorech (ukazatelích) výkonu žáka a za tyto indikátory se považují právě specifikace očekávaných výstupo̊. Interpretace specifikací očekávaných výstupů jako indikátorů žákovského výkonu však neodpovídá přesně pojetí indikátoru, jak je chápán v literatuře (viz Janoušková, Maršák, 2008; Bunge, 2003; Shavelson, 1991; van Ackeren, 2000; Hák ed., 2007 a další). Účelem indikátorů, v nejobecnějším slova smyslu, je totiž objektivní a pokud možno spolehlivé sledování vlastností objektů (nebo systémů těchto objektů) daného druhu či procesů, které v těchto objektech či mezi nimi probíhají (Janoušková and Maršák, 2008). $\mathrm{V}$ užším pojetí pak lze indikátory považovat za nástroje vytvářené a zaváděné za účelem hodnocení a informování, tedy zejména proto, aby umožnily posoudit, zda bylo dosaženo předem definovaných záměrů resp. cílů vymezených v dané oblasti zkoumání a zda jsou za daných podmínek záměry resp. cíle dosahovány optimálním způsobem (viz např. Ogawa and Collom, 2000; Shavelson et al., 1991; Dlouhá, 2007). Objektivní hodnocení však není možné dosáhnout bez toho, aby byla využita nějaká metoda, kterou budou sbírána data pro možnost získání kýžené informace.

Je to tedy např. úloha, resp. její řešení žákem, co bude indikovat žákův výkon a přinese informaci o tom, zda vymezený standard byl dosažen nebo ne. Tudíž, specifikace očekávaných výstupů sama o sobě nic neindikuje, jen konkretizuje jejich význam a teprve doplnění takto specifikovaného výstupu úlohou nebo jinou metodou měření žákova výkonu tvoří indikátor jako takový. Evaluační standardy by tedy vždy měly ideálně přinášet tzv. indikátorové listy, které přinesou vyčerpávající informace o způsobu získávání a také způsobu vyhodnocování a interpretaci dat.

\section{EVALUAČNí STANDARDY PRO VZDĚLÁVACÍ OBOR CHEMIE}

V našem článku bychom se nyní zaměřili na vzdělávací standardy pro vzdělávací obor Chemie, které jsou součástí Standardů základního vzdělávání. Jako tvůrci těchto standardů bychom rádi vysvětlili naše záměry, které jsme uplatnili při jejich tvorbě, a přinesli ukázku dvou možných kompletních indikátorových listů pro naplnění rozpracovaných výstupů, které jsou nyní ve Standardech základního vzdělávání uvedeny jako „rozpracované očekávané výstupy“ a jsou v tomto dokumentu ne právě štastně nazývány indikátory.

Podotýkáme, že předložené indikátorové listy jsou příkladem z našeho pohledu optimálního zpracování podoby indikátoru pro účely evaluace na jakékoli úrovni. Nároky MŠMT na zpracování indikátorů byly ovšem jiné, i když původně byly i v rámci projektu MŠMT pro zpracování Standardů základního vzdělávání uvedeny u rozpracovaných očekávaných výstupů alespoň konkrétní ilustrační úlohy, které ovšem následně do připomínkového řízení nebyly zařazeny.

Jako tvůrci standardu vzdělávacího oboru Chemie jsme vycházeli z několika předpokladů. Evaluační standard by neměl popřít Rámcový vzdělávací program pro 
základní vzdělávání jakožto aktuálně platný standard vzdělávání. Měl by sledovat v něm uvedené výstupy a to i z hlediska náročnosti kognitivního výkonu žáka a napomáhat v rozvoji kompetencí, které, at už je nazíráme jakkoli, pomáhají žákovi v jeho osobním i profesním životě. Jinými slovy, minimální evaluační standard by neměl co do obsahového i cílového vymezení aktuálně platný standard pro základní vzdělávání - RVP ZV rozšiřovat ani zužovat. Dále by evaluační standard měl respektovat fakt, že tvoříme výstupní hodnocení žáka za určité období a testovat by se tak měly skutečně základní znalosti a dovednosti žáka po ukončení tohoto období, nikoli znalosti „průběžné“. I proto je evaluační standard zpracován jen pro devátý ročník základní školy a ekvivalentní ročník víceletých gymnázií. Podrobné ověřování vzdělávacích výsledků žáků v daných ročnících, ve kterých je učivo probíráno detailněji, by mělo být realizováno školami. Konečně se domníváme, že základní znalosti by měly být zejména takové, které žákovi usnadní jeho život profesní i osobní a zároveň přispějí k jeho rozvoji tak, aby byl kompetentní i z občanského hlediska (např. aby měl základní povědomí o ochraně životního prostředí, chování v případě havárií, nebo byl schopen chránit zdraví své i ostatních).

Vhodnou reflexí vytvořených standardů bylo potom připomínkové řízení, které mohlo poukázat na nedostatky ve vytvořeném standardu. Připomínkové řízení ukázalo, že jak oboroví didaktici z řad vysokoškolských odborníků, tak učitelé základních škol a ekvivalentních ročníků víceletých gymnázií se s touto myšlenkou pravděpodobně ztotožňují a připomínek $\mathrm{z}$ jejich řad přišlo jen velmi málo. Zůstává ovšem otázkou, nakolik byly zájmové skupiny osloveny a do připomínkového řízení se zapojily. V každém případě na základě proběhnuvšího řízení se ukazuje, že v prŕípadě vzdělávacího oboru Chemie se podařil vytvořit základ evaluačního standardu, tedy vymezení sledovaného faktu - rozpracované očekávané výstupy, který se pohybuje $\mathrm{v}$ intencích $\mathrm{v}$ současnosti platného RVP ZV.

\section{INDIKÁTOROVÉ LISTY}

Jak jsme uvedli v rešeršní části článku, indikátor by měl být ideálně stanoven v ucelené podobě. Např. indikátory sledující v rámci implementace konceptu udržitelného rozvoje proměnu fyzického či sociální prostředí jsou vybaveny tzv. indikátorovými listy (indicator fact sheets) nebo metodologickými listy (methodological fact sheets). Obojí má stejný účel - umožnit provádět evaluační proces stále stejným způsobem a získávat tak dlouhé časové řady dat vztahující se k sledovanému faktu. Indikátorové listy vždy indikátor vymezují - definují, tedy říkají, jaký fakt pomocí něj bude vizualizován, uvádějí způsob měření sledovaného faktu a v případě, že existuje jednotka měření sledovaného faktu, i tuto jednotku. Dále obsahují návod na vyhodnocování dat - tam, kde není metoda vyhodnocování obecně známou, a způsob interpretace dat. Tyto uvedené kategorie bývají nejobvyklejší, protože jsou pro evaluační procesy nezbytné. Indikátorové listy mohou obsahovat ale i kategorie další, např. odkazovat na indikátory měřící v systému související fakta nebo relevanci indikátoru pro politické rozhodovací procesy.

My jsme pro představení dvou indikátorů využili pouze základní verze indikátorového listu, doplněnou pouze vazbou na RVP ZV. Vymezení sledovaného faktu, který bude indikován, představuje $\mathrm{v}$ našem př́ípadě rozpracovaný očekávaný výstup RVP ZV. Ten blíže specifikuje žákovu znalost nebo dovednost v některém z tematických okruhů vzdělávací oblasti oboru Chemie. Metod měření žákovského výkonu může být širší škála, ale protože primárně byly evaluační standardy vytvářeny za 
Tab. 1: Indikátorový list číslo 1 k tematickému okruhu: Anorganické sloučeniny

\begin{tabular}{|c|c|}
\hline $\begin{array}{l}\text { Vymezení sledovaného faktu } \\
\text { (rozpracovaný očekávaný výstup) }\end{array}$ & $\begin{array}{l}\text { Žák uvede způsob, jakým by změřil pH } \\
\text { kapaliny. }\end{array}$ \\
\hline Metoda měření & $\begin{array}{l}\text { Testová úloha } \\
\text { Ilustrační úloha } 1 \text { - úloha uzavřená } \\
\text { Přítomnost kyselých látek z ovzduší, které } \\
\text { se pohlcují ve vodě, zjistíme zachycením } \\
\text { srážek do plastové nádoby a jejím násled- } \\
\text { ným: } \\
\text { (Zakroužkujte písmeno u správné odpovědi) } \\
\text { A. přefiltrováním } \\
\text { B. změřením hustoty } \\
\text { C. změřením pH indikátorovým papír- } \\
\text { kem } \\
\text { D. smísením s kuchyňskou solí a násled- } \\
\text { ným odpařením } \\
\text { E. smísením s roztokem hydroxidu sod- } \\
\text { ného } \\
\text { Ilustrační úloha } 2 \text { - úloha otevřená } \\
\text { Navrhněte postup, kterým byste zjistili, } \\
\text { že zem na vaší zahrádce je kyselá, } \\
\text { neutrální nebo zásaditá. }\end{array}$ \\
\hline Vyhodnocování dat & $\begin{array}{l}\text { Ilustrační úloha } 1 \text { - úloha uzavřená } \\
\text { Správná odpověd' - } 1 \text { bod } \\
\text { Chybná odpověd' - } 0 \text { bodů } \\
\text { Ilustrační úloha } 2 \text { - úloha otevřená } \\
\text { Zcela správně popsaný pracovní postup - } \\
2 \text { body } \\
\text { Cástečně správně popsaný pracovní } \\
\text { postup - } 1 \text { bod } \\
\text { Chybně popsaný pracovní postup - } \\
0 \text { bodů }\end{array}$ \\
\hline Interpretace dat & $\begin{array}{l}\text { Ilustrační úloha } 1 \text { - úloha uzavřená } \\
1 \text { bod - žákovská znalost je úplná } \\
0 \text { bodů - žák danou znalostí nedisponuje } \\
\text { Ilustračni úloha } 2 \text { - úloha otevřená } \\
2 \text { body - žákovská znalost je úplná } \\
1 \text { bod - žákovská znalost je neúplná, ale } \\
\text { žák naznačil alespoň zčásti možnost řešení } \\
0 \text { bodů - žák danou znalostí nedisponuje }\end{array}$ \\
\hline $\begin{array}{l}\text { Návaznost na očekávaný výstup } \\
\text { Rámcového vzdělávacího programu } \\
\text { pro základní vzdělávání }\end{array}$ & $\begin{array}{l}\text { Žák se orientuje se na stupnici pH, změří } \\
\text { reakci roztoku univerzálním indikátorovým } \\
\text { papírkem a uvede přiklady uplatňování } \\
\text { neutralizace v praxi. }\end{array}$ \\
\hline
\end{tabular}


Tab. 2: Indikátorový list číslo 2 k tematickému okruhu: Směsi

\begin{tabular}{|c|c|}
\hline $\begin{array}{l}\text { Vymezení sledovaného faktu } \\
\text { (rozpracovaný očekávaný výstup) }\end{array}$ & $\begin{array}{l}\text { Žák rozlišuje nasycený a nenasycený } \\
\text { roztok. }\end{array}$ \\
\hline Metoda měření & $\begin{array}{l}\text { Testová úloha } \\
\text { Ilustrační úloha } 1 \text { - úloha uzavřená } \\
\text { Učitel ve třídě nechal žáky připravit } \\
\text { nasycený roztok chloridu sodného - } \\
\text { kuchyňské soli. Ve třídě ustanovil } \\
4 \text { skupiny žáků. Každá ze skupin } \\
\text { postupovala jinak. } \\
\text { První skupina lžičku soli rozdrtila } \\
\text { v třecí misce, přesypala ji do kádinky, } \\
\text { zalila studenou vodou a zamíchala. } \\
\text { Druhá skupina lžičku soli nechala } \\
\text { v původním stavu, umístila ji do kádinky, } \\
\text { zalila studenou vodou a další sůl } \\
\text { přisypávala za stálého míchání do té doby, } \\
\text { dokud se v roztoku rozpouštěla. } \\
\text { Třetí skupina žáků lžičku soli } \\
\text { nerozdrtila, zalila ji teplou vodou } \\
\text { a zamíchala. } \\
\text { Čtvrtá skupina sůl rozdrtila, zalila ji } \\
\text { teplou vodou a za stálého míchání } \\
\text { přisypávala do roztoku další sůl do té } \\
\text { doby, dokud se v roztoku rozpouštěla. } \\
\text { a) Kolik skupin připravilo nasycený } \\
\text { roztok? } \\
\text { b) Uved’te skupinu (skupiny), které na- } \\
\text { sycený roztok nepřipravily. }\end{array}$ \\
\hline Vyhodnocování dat & $\begin{array}{l}\text { Ilustrační úloha } 1 \text { - úloha uzavřená } \\
\text { a) Správná odpověd' - } 1 \text { bod } \\
\text { Chybná odpověd' - } 0 \text { bodů } \\
\text { b) Správná odpověd' - } 1 \text { bod } \\
\text { Chybná odpověd' - } 0 \text { bodů }\end{array}$ \\
\hline Interpretace dat & $\begin{array}{l}\text { Ilustrační úloha } 1 \text { - úloha uzavřená } \\
1 \text { bod - žákovská znalost je úplná } \\
0 \text { bodů - žák danou znalostí nedisponuje }\end{array}$ \\
\hline $\begin{array}{l}\text { Návaznost na očekávaný výstup } \\
\text { Rámcového vzdělávacího programu } \\
\text { pro základní vzdělávání }\end{array}$ & $\begin{array}{l}\text { Žák vysvětlí základní faktory ovlivňující } \\
\text { rozpouštěni pevných látek. }\end{array}$ \\
\hline
\end{tabular}


účelem plošného získávání informací o vzdělávacích výsledcích žáků, zvolili jsme jako metodu měření testovou úlohu. Jsme si ale plně vědomi toho, že škála metod je daleko širší. Vyhodnocování dat v našem případě představuje vyhodnocení testové úlohy. Zde jsme vycházeli z běžné praxe mezinárodních výzkumů žákovských znalostí a dovedností v oblasti přírodních věd PISA a TIMSS a za řešení správné - částečně správné - nesprávné jsme přiřazovali určitý počet bodů, které potom umožní snadnou interpretaci získaných dat (viz tab. 1 a 2). Domníváme se, že takto zpracovaný indikátorový list by umožnil opravdu objektivní debatu nad současnými evaluačními standardy a přinesl komplexní představu o způsobu potencionálního sběru informací o vzdělávacích výsledcích žáků. Vyhovoval by tak lépe potřebám odborné i laické veřejnosti.

\section{ZÁvĚR}

Když v roce 2001 vyšel Národní program rozvoje vzdělávání, tzv. Bílá kniha, řada odborníků z řad pedagogů zaznamenala plán testovat $\mathrm{v}$ budoucnosti žáky pátých a devátých ročníků základních škol. Tenkrát se odborná ale i laická veřejnost rozdělila na dvě skupiny. Skupina zastánců testování argumentovala možností srovnávání vzdělávacích výsledků žáků na různých školách, možností snadné prostupnosti žáků do nižších ročníků víceletých gymnázií nebo posléze středních škol bez přijímacích zkoušek a možností srovnání žáků také v mezinárodním kontextu. Skupina odpůrců testování varovala před vytvářením žebříčků škol, zaměření škol na přípravu žáků na testování, tedy zejména memorování znalostí a na fakt, že testové úlohy neověří to, co mělo přinést zavedení rámcových vzdělávacích programů, tedy ověření míry naplnění klíčových kompetencí žáků. Argumenty obou skupin jsou velmi pádné a kopírují názory, které se s plošným sběrem dat o znalostech a dovednostech žáků objevují rovněž v zahraničí.

Jestliže dojde ke shodě na plošném získávání informací o vzdělávacích výsledcích žáků, pak nám přijde velmi podstatné, přinést komplexní informace o indikátorech, na jejichž základě budou data shromaždována. Jako ideální se nám pro tento účel zdají být indikátorové listy, které přináší rychlou komplexní informaci o způsobu hodnocení žáků pro odbornou, ale i laickou veřejnost. Výhoda těchto listů spočívá zejména $\mathrm{v}$ tom, že evaluační standardy by přinášely vskutku jen takové výstupy žákovských znalostí, dovedností a schopností, které jsou měřitelné příslušnými metodami pedagogiky, navíc by byly jednoduše reprodukovatelné a interpretovatelné.

Domníváme se, že pokud by evaluační standardy sloužily ke sběru dat o vzdělávacích výsledcích žáků dlouhodobě na základě těchto jednoduše aplikovatelných indikátorových listi̊, vznikl by v rámci Ceské republiky zajímavý průzkum znalostí a dovedností českých žáků v př́slušných oborech. Casové řady získaných dat by pomohly objektivně zhodnotit vývoj vzdělání žáků v daných oborech a přispěly by k dlouhodobé evaluaci vzdělávacího systému, po které se řadu let volá. Věříme, že pokud by evaluační standardy nebyly represivním nástrojem, ale skutečnou pomocí v úsilí pedagogických pracovníků, byl by evaluační standard přijímán odbornou i laickou veřejností kladně.

\section{LITERATURA}

van ACKEREN, I., HOVESTADT, G. Indikatorisierung der „Forum-Bildung“ Empfehlungen - Ein exemplarischer Versuch unter Berücksichtigung der bildun- 
gsbezogenen Indikatorenforschung und - Entwicklung. Essen : Universität Duisburg: Arbeitsgruppe Bildungsforschung/Bildungsplanung, 2003.

BUNGE, M. Philosophical Dictionary, Enlarged Edition. Amherst, New York : Prometheus Books, 2003. ISBN 1-59102-037-9.

DLOUHÁ, J. Indikátory pro strategie environmentálního vzdělávání, Envigogika 2007/II/3 [on-line]. 2007. [cit. 2010-10-28]. Dostupné na WWW:

〈http://www.envigogika.cuni.cz/envigogika-2007-ii-3/

indikatory-pro-strategie-environmentalniho-vzdelavani_cs $\rangle$

HÁK, T., MOLDAN, B., DHAL, A. L. (eds.). Sustainability Indicators: A Scientific Assessment. 1st. Edition. Washington : Island Press, 2007. SCOPE Series/67. ISBN 978-1-59726-130-2.

JANOUŠKOVÁ, S., MARŠAK, J. Indikátory - významný prostředek našeho poznávaní. Pedagogika, 2008, roč. 58, č. 1, s. 29.

MINISTERSTVO ŠKOLSTVÍ, MLÁDEŽE A TĚLOVÝCHOVY (MŠMT): Dlouhodobý záměr vzdělávání a rozvoje vzdělávací soustavy ČR (2011-2015). [online]. 2011. [cit. 2012-01-28]. Dostupné na WWW: 〈http://www.atre.cz/zakony/page0556.htm〉

OGAWA, R., COLLOM, E. Using Performance Indicators to Hold Schools Accountable: Implicit Assumptions and Inherent Tensions. Peabody Journal of Education. 2000, vol. 75, no. 4, s. 200-215. ISSN 1532-7930.

Rámcový vzdělávací program pro základni vzdělávání. Praha : Výzkumný ústav pedagogický v Praze, druhý dotisk 1. vyd., Tauris, 2005. ISBN 80-87000-02-1.

Rámcový vzdělávací program pro gymnázia. Praha : Výzkumný ústav pedagogický v Praze, 2007. ISBN 978-80-87-000-11-3.

Standard pro základní vzdělávání (SZV). Praha : Fortuna, 1999, 56 s.

ISBN 80-7168-602-6.

Standard vzdělávání ve čtyřletém gymnáziu (SVG). Praha : Fortuna. 1999. 47 s. ISBN 80-7168-603-4.

Standardy základního vzdělávání (SZV). (Verze pro připomínkové řízení). [online]. 2011. [cit. 2012-01-28]. Dostupné na WWW:

〈http://diskuze.rvp.cz/viewtopic.php?f $=549 \& \mathrm{t}=17681\rangle$

a $\langle$ http://www.vuppraha.cz/standardy-chemie-9

SHAVELSON, R. J., MCDONNEL, L., OAKS, J. What are educational indicators and indicator systems? Practical Assessment, Research and Evaluation [online]. 1991a, vol. 2, no. 11, [cit. 2006-12-28].

Dostupné na WWW: 〈http://pareoline.net/getvn.asp?v=2\&n=11〉. ISSN 1531-7714.

Učební dokumenty pro gymnázia. Praha : Fortuna. 1999. 205 s. ISBN 80-7168-659-X.

RNDr. Svatava Janouškova, Ph.D. - E-mail: svatava.janouskova@czp.cuni.cz

Centrum pro otázky životního prostředí Univerzity Karlovy v Praze, Česká republika

RNDr. Jan Maršák, CSc. - E-mail: jmarsak@seznam.cz

Publikuje jako nezávislý odborník na danou problematiku, Ceská republika

PhDr. Václav Pumpr, CSc. - E-mail: vaclav.pumpr@centrum.cz

Publikuje jako nezávislý odborník na danou problematiku, Česká republika 